\title{
Palatability of Annual and Perennial Legumes
}

\author{
Atanas Kirilov, Ina Stoycheva and Viliana Vasileva* \\ Department of Technology and Ecology of Forage Crops, Institute of Forage Crops, Bulgaria
}

Submission: November 14, 2016; Published: November 23, 2016

*Corresponding author: Viliana Vasileva, Department of Technology and Ecology of Forage Crops, Institute of Forage Crops, Pleven, Bulgaria, Europe, Email: viliana.vasileva@gmail.com

\begin{abstract}
The study aimed to compare the palatability of green mass of whole plant of perennial legumes, i.e. alfalfa, sainfoin and birdsfoot trefoil; annual legumes, i.e. soybeans, chickpeas, peas, vetch, broad beans, and grain of peas, chickpeas, broad beans, and nontreated and thermal-treated soybeans, by the so-called "cafeteria manger" method with rams. Alfalfa was the most palatable, followed by sainfoin. The palatability of birdsfoot trefoil was two times lower as compared to sainfoin and six times lower as compared to alfalfa. Alfalfa showed the highest palatability when compared to annual legumes, too. Vetch showed the highest palatability from the annual legumes, but peas, chickpeas, soybeans and broadbeans showed very low palatability. For the grain from legumes-soybeans showed the highest palatability, followed by the grain of peas and vetch. Thermal-treated grain from soybeans had a 39\% lower palatability as compared to non-treated. Chickpeas and broad beans had approximately zero palatability. Alfalfa could be considered as a standard for comparing palatability or consumption of legumes, both annual and perennial ones.
\end{abstract}

Keywords: Chemical composition; Palatability; Legumes

\section{Introduction}

Recently Europe's policy is aimed at encouraging the cultivation of legumes with the purpose to use their nitrogenfixing ability and thereby to reduce their needs for fertilization with mineral nitrogen and to provide more protein from own sources in feeding animals $[1,2,3]$. Thanks to its nitrogen-fixing capabilities they absorb nitrogen from the air, which reduces the need for nitrogen fertilizers [4,5]. For this reason, the agricultural policy of the EU and individual countries to financially stimulate and increase the area under legumes has a dual purpose, on the one hand, environmental, on the other, providing more protein from own sources in animal nutrition. One part of legumes such as soybeans, peas, chickpeas, broad beans are grown for the receipt of grain, and another part, mostly perennials, such as alfalfa, birds foot trefoil for making hay or green forage, including as components of mixtures for grazing.

Some of the annual grain legumes can be used, except as a grain, and overall plant for green forage or hay, including straw after threshing of grain. This increased interest in the legumes obliges us to turn our attention once again of their feed value and their suitability to satisfy the nutritional needs of animals. The forage characteristics is a concept that implies the presence of many indicators relating to the structure of plants, chemical composition, digestibility, consumption, energy and protein nutrition. Some of these characteristics are easy to define, others require prolonged and severe experiments with animals, but there are those who give an indirect characterization for the nutritional value of forage plants and are easy to determine. Such an indicator is the palatability, which gives an idea of forage consumption. The palatability is a relative value that accumulates all forage attributes associated with uptake and nutritional qualities of forage $[6,7]$.

For palatability of forage is judged by the quantity of forage consumed during the main meal, the first after betting on the feed or the quantity of feed consumed in the free access to more than one feed $[8,9,10]$. The purpose of this study was to compare the palatability of green mass of alfalfa, sainfoin, birdsfoot trefoil, peas, soybeans, vetch, chickpeas and beans, and grain from peas, soybeans, vetch, chickpeas by the so-called "cafeteria manger" method with rams.

\section{Materials and Methods}

The trials were conducted in the Institute of Forage Crops, Pleven, Bulgaria. There were three experiments, two of them were carried out with green forages and one with grains of legumes. In one of the three experiments the palatability of cut green mass from alfalfa, birds foot trefoil and sain foin, in the other - from peas, vetch, chick peas, soybeans, beans, and 
in the third -a grain of peas, vetch, chick peas, broad beans and untreated and thermal-treated soybeans. In the experiment with grain the variant with grain of the soybean, which has passed through installation to cook, heat at $140^{\circ} \mathrm{C}$ for $25-30$ seconds in order to eliminate the antitripsin inhibitor and its direct use in animal nutrition [11].

Green forages are compared in the flowering-pod formation stage. The palatability is defined with 5 rams of the breed Blackface sheep. The animals came free, individualized, simultaneous access on three consecutive days to equal amounts of the tested forage. From the green forages $1.0 \mathrm{~kg}$ and from grains $0.2 \mathrm{~kg}$ was suggested. The amount of forages consumed during the first 15 minutes of the meal, the palatability of every forage was determined. The total quantity consumed of all submitted forages is accepted for $100 \%$ and the quantity consumed of each feed, calculated its relative part of the total consumption quantity. Like the most palatable is considered that forage from which animals have consumed the greatest amount. The values obtained for the palatability are relative, valid for the group compared to forage and give a general idea of their feed. Method for determination of the palatability is called "cafeteria manger" [12]. From each forage samples were taken for chemical analysis, determined by generally accepted laboratory methods.

\section{Results and Discussions}

Table 1: Chemical composition of grain and green mass of legumes (\% of DM).

\begin{tabular}{|c|c|c|c|c|c|}
\hline Forage & CP & CF & CFats & Ash & NEE \\
\hline \multicolumn{6}{|c|}{ Grain } \\
\hline Pea & 27.92 & 4.23 & 1.14 & 3.88 & 62.83 \\
\hline Vetch & 32.4 & 3.41 & 0.78 & 3.38 & 60.03 \\
\hline Chick peas & 21.4 & 2.57 & 5.72 & 3.52 & 66.79 \\
\hline Soybean & 37.17 & 14.96 & 21.36 & 5.25 & 21.26 \\
\hline $\begin{array}{c}\text { Thermal-treated } \\
\text { soybean }\end{array}$ & 37.11 & 15.49 & 22.82 & 5.44 & 19.14 \\
\hline Broad beans & 26.51 & 5.41 & 1.56 & 3.74 & 62.82 \\
\hline \multicolumn{6}{|c|}{ Green mass } \\
\hline Alfalfa & 17.36 & 27.84 & 2.32 & 9.85 & 42.63 \\
\hline Sainfoin & 17.53 & 20.08 & 3.12 & 8.1 & 51.17 \\
\hline Birdsfoot trefoil & 17.14 & 25.63 & 3.14 & 8.77 & 45.32 \\
\hline Peas & 13.04 & 25.06 & 2.14 & 8.01 & 48.3 \\
\hline Vetch & 17.48 & 27.14 & 2.14 & 11.46 & 41.78 \\
\hline Chick peas & 14.06 & 27.14 & 3.44 & 11.32 & 44.04 \\
\hline Soybeans & 13.13 & 29.87 & 2.48 & 9.02 & 45.5 \\
\hline Broad beans & 17.07 & 14.87 & 2.99 & 10 & 55.07 \\
\hline
\end{tabular}

In Table 1 characteristics of chemical composition of the forages tested are given. With the highest crude protein content in grain of legumes was soybeans $-37 \%$ of dry matter. The majority of the legumes used as a green mass of the whole plant had similar values in content of crude protein - $17-18 \%$ of dry matter. With lower protein content in our case were soybeans, chick peas and peas. These differences probably are due to the differences in the development of any type of forage crop and different time and duration of phenological stages of development. The results of the palatability of three perennial legumes are given in Figure 1. With the highest palatability was alfalfa $-65.66 \%$ of the total consumption quantity. Secondly the quantity consumed, as a proportion of the total, was ranked the sainfoin, and with the lowest -birds foot trefoil. The palatability of birds foot trefoil was two times lower than that of sainfoin and six times lower than of alfalfa. In our previous studies it was found that when eating at will with a green alfalfa, as the only forage the rams have started training with the alfalfa over two times more net energy, while sainfoin in flowering stage assumption is 1.7-1.8 times over the level of maintenance. This indirect comparison shows that the definition of the palatability of the forages gives an idea of their real consumption by animals.

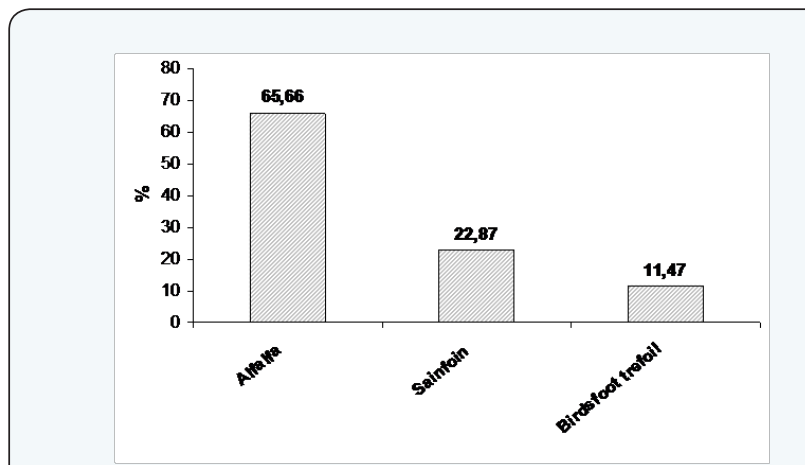

Figure 1: Palatability of alfalfa, sainfoin and birdsfoot trefoil, \% from the total consumption.

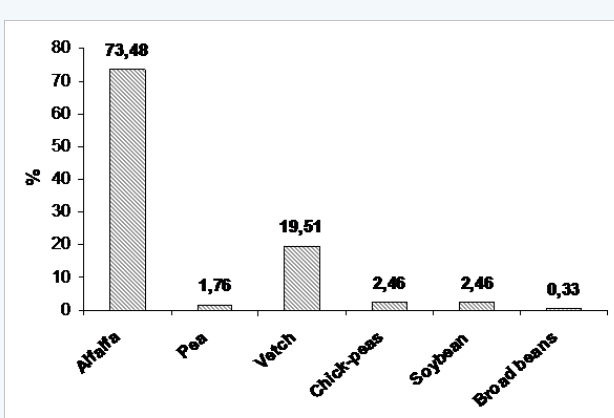

Figure 2: Palatability of green mass of alfalfa, pea, vetch, chickpeas, soybean and broad beans, \% from the total consumption.

Alfalfa has the highest palatability $-73.5 \%$ of consumption in the comparison with the palatability of annual legumes as peas, vetch, chick peas, soybeans and beans (Figure 2). Secondly after alfalfa and at first between annual legumes ranked vetch. The others including peas, chickpeas, broad beans and soybeans showed very low palatability. Probably with the presence of the coarse stems can explain some of these results in soybeans and chick peas, as well as the differences in flavor, caused by the 
different smell of individual species of forage plants. The high palatability of alfalfa can be accepted as a criterion and standard when comparing palatability or consumption of perennial legume and annual forage crops.

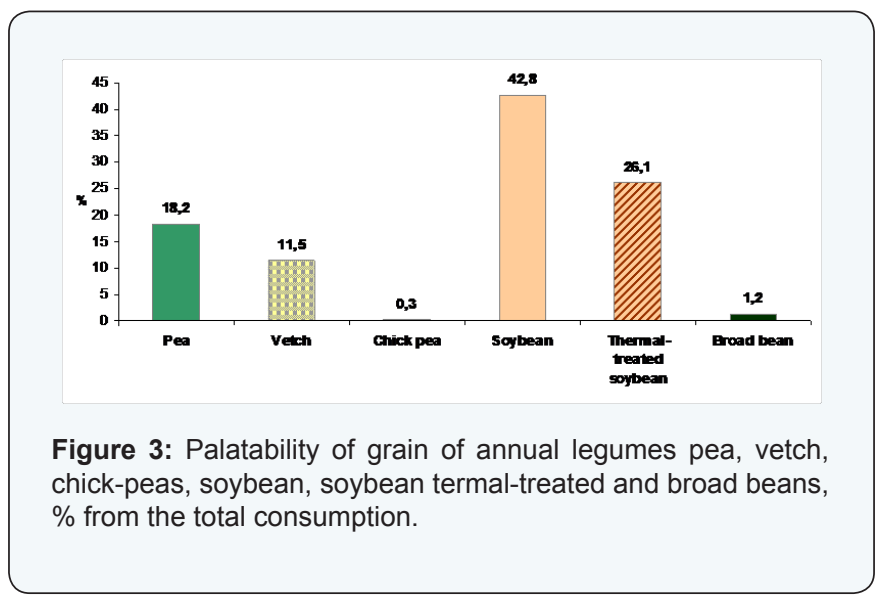

In grain legumes with the highest palatability was grain of soybeans, followed by peas and vetch (Figure 3). Thermal-treated grain of soybean had palatability with $39 \%$ less than untreated soybean grains. This negative effect of thermal treatment on the consumption of soybeans has been observed and in experience with sheep [11]. we have to take into consideration the taste requirements of animals to forage. Chick-peas and field bean had very low, almost zero palatability. Probably their low palatability will be one of the limiting factors for inclusion in animal rations.

\section{Conclusion}

Alfalfa was the most palatable, followed by sainfoin. The palatability of birdsfoot trefoil was two times lower as compared to sainfoin and six times lower as compared to alfalfa. Alfalfa showed the highest palatability when compared to annual legumes, too. Vetch showed the highest palatability from the annual legumes, but peas, chickpeas, soybeans and broadbeans showed very low palatability. For the grain from legumes soybeans showed the highest palatability, followed by the grain of peas and vetch. Thermal-treated grain from soybeans had a $39 \%$ lower palatability as compared to non-treated. Chickpeas and broad beans had approximately zero palatability. Alfalfa could be considered as a standard for comparing palatability or consumption of legumes, both annual and perennial ones.

\section{References}

1. Pypers P, Verstraete S, Cong Phan Thi, Merckx R (2005) Changes in mineral nitrogen phosphorus availability and salt-extractable aluminium following the application of green manure residues in two weathered soils of South Vietnam. Soil Biology and Biochemistry 37: 163-172.

2. Luscher A, Mueller Harvey I, Soussana JF, Rees RM, Peyraud JL (2014) Potential of legume-based grassland-livestock systems in Europe: a review. Grass Forage Sci 69(2): 206-228.

3. Kusvuran A, Ralice Y, Saglamtimur T (2014) Determining the Biomass Production Capacities of Certain Forage Grasses and Legumes and their Mixtures under Mediterranean Regional Conditions. Acta Advances in Agricultural Sciences 2: 13-24.

4. Vance CP (2001) Symbiotic nitrogen fixation and phosphorus acquisition. Plant nutrition in a world of declining renewable resources. Plant Physiol 127(2): 390-397.

5. Graham PH (2008) Ecology of the root-nodule bacteria of legumes. In: Dilworth MJ, James EK, Sprent JI (Eds.), Nitrogen fixing leguminous symbiosis. Springer Netherlands, Europe, p. 23-58.

6. Emil JC, Ghesquiére M, Traineaau R, Jadas-Hecart J, Mousset C (1997) Evaluation de la valeur alimentaire de génotypes de fétuque élévéee obtenus par difféerents stratégies d'amélioration. Fourrage 151: 373387.

7. Julie B, Huighe C (1998) Variabilité génétique pour la digestibilité de la Lucerne : relation avec la production de matière sèche et la proportion de feuilles. Fourrage 154: 261-268.

8. Dulphy JP (1971) Influence du poid vif et du niveau d'ingestion sur comportement alimentaire et merycique du mouton. Ann Zootech 20: 477-486.

9. Dulphy JP, Demarquilly C (1994) The regulation and prediction of feed intake in ruminants in relation to feed characterics. Livestock Production Science 39(1): 1-12.

10. Kirilov A, Vasilev E, Dimitrova A (2006) Assessment of palatability of different grass and legume species, and their combination. In: Sustainable Grassland Productivity (Eds) Loveras L, GonzalezRodriguez A, Vazquez-Yanez O, Grassland Science in Europe 11: 363365.

11. Kirilov A, Vasilev E, Vasileva V, Popp T (2015) The effect of different forms of potash fertilizers on yield and composition of alfalfa and cocksfoot in pure stand and mixture II Chemical composition and palatability. Proc International Symposium on "Nutrient Management and Nutrient Demand of Energy Plants", Budapest, Hungary, p. 7.

12. Gillet M, Noel C, Jadas Hecart L (1983) La cafeteria d'auges, method d'etude de l'appetibilite des fourrages. Agronomie 3(8): 817-882. 
Your next submission with JuniperPublishers will reach you the below assets

- Quality Editorial service

- Swift Peer Review

- Reprints availability

- E-prints Service

- Manuscript Podcast for convenient understanding

- Global attainment for your research

- Manuscript accessibility in different formats ( Pdf, E-pub, Full Text, Audio)

- Unceasing customer service

Track the below URL for one-step submission http://juniperpublishers.com/online-submission.php 